\begin{tabular}{|c|c|}
\hline PORT SAID ENGINEERING RESEARCH JOURNAL \\
Faculty of Engineering - Port Said University \\
Volume 16 No. 1 pp: 97:105
\end{tabular}

\title{
Effect of Limestone Waste as Partial Replacement Material for Sand and Silica Fume in Concrete
}

\author{
Hassan A. Mohamadien ${ }^{1}$, Ghada D. Abd Elhameed ${ }^{2}$, Mohamed A. Sherif ${ }^{3}$, Omar M. Omar ${ }^{4}$
}

\begin{abstract}
This paper presents the results of a study to compare the properties of concretes prepared with the use river sand, limestone waste (LSW), and silica fume (S.F). Two different types of concrete mixture were prepared, and tested in fresh and hardened states. Except for control concrete, quarry waste fine aggregate was used in all concretes as a partial replacement of natural sand. The effects of quarry waste fine aggregate on several fresh and hardened properties of the concretes were investigated. It was found that quarry waste fine aggregate enhanced the slump test of the fresh concretes. But the unit weight concretes were not affected. The investigation included testing of compressive strength, indirect tensile strength, flexural strength, modulus of elasticity, and permeability. However, the best performance was observed when quarry waste fine aggregate was used in presence of silica fume. The overall test results revealed that quarry waste fine aggregate can be utilized in concrete mixtures as a good substitute of natural sand.
\end{abstract}

Keywords: Hardened, LSW, Materials, Sand, Silica Fume, Concrete

Nomenclature: (LSW) limestone waste, (S.F) silica fume, manufactured sand (MS), N*: normal concrete 0.0\% (S.F) \& $0.0 \%$ (LSW), N25: $0.0 \%$ (S.F) \& replacement sand 25\% with (LSW) N50: $0.0 \%$ (S.F) \& replacement sand 50\% with (LSW), N75:0.0\% (S.F) \& replacement sand 75\% with (LSW)

\section{1- Introduction}

Green concrete has nothing to do with color. It is a concept of thinking environment into concrete considering every aspect from raw materials manufacture over mixture design to structural design, construction, and service life. The concrete industry is known to leave an enormous environmental footprint on planet earth. Limestone waste is obtained as a by-product during the production of aggregates through the crushing process of rocks in rubble crusher units. Usually quarry waste is used in large scale as a surface finishing material in highways. Quarry waste has also good potential for producing normal and lightweight concretes ${ }^{1,2}$. T. Celikand K. Marar $^{3}$ studied the effect of replacement of sand with limestone waste on slump test with different volume $(0,5,10,15,20,25$, and 30$)$. It was found that, as the percentage of dust in the concrete increases, the slump of concrete decreases. Also, they concluded that the compressive strength in 7 and 28 days increases to a maximum of 22.47 and 32.38 MPa respectively at a dust content of $10 \%$. As the dust content exceeds the value of $10 \%$, the compressive strength decreases. For specimens of

\footnotetext{
${ }^{1}$ Associate Professor, Department of civil engineering, Faculty of Engineering, Suez Canal University, Egypt

${ }^{2}$ Lecturer, Building Materials Research and Quality Control Institute, Housing and Building National Research Center, Egypt

${ }^{3}$ Lecturer, Department of Civil Construction and Architecture, Faculty of Industrial Education, Suez, Egypt

${ }^{4}$ Demonstrator, Department of Civil Construction and Architecture, Faculty of Industrial Education, Suez, Egypt
}

dust content percentages of 0 , and 5 , the dust particles amount is not enough to fill all voids between cement paste and aggregate particles; hence they have lower compressive strength values than specimens of with $10 \%$ dust content. As the dust content exceeds $10 \%$, the amount of fines in the concrete increases, so much that, there is not enough cement paste to coat all the coarse and fine aggregate particles, and this consequently leads to a decrease in compressive strength. Beixing et al., ${ }^{4}$ found that incorporation of up to $15 \%$ limestone fines as a partial replacement for fine aggregate in lowstrength manufactured sand (MS) concrete or 10\% limestone fines for in high-strength (MS) concrete improved compressive strength . R. Ilangovana et. al., ${ }^{5}$ found that the natural river sand, if replaced by hundred percent quarry rock dust from quarries, may some times give equal or better than the reference concrete made with Natural Sand, in terms of compressive and flexural strength.

\section{2- Research Program}

The experimental test program was designed to achieve the research objectives of the study. The program consists of two phases; phase I with cement content $350 \mathrm{~kg} / \mathrm{m}^{3}$. One mix was control (normal concrete mix), three mix incorporating lime stone waste $25 \%, 50 \%$, and $75 \%$ replacement from sand. Twelve mixes incorporating lime stone waste $0.0 \%$, $25 \%, 50 \%$ and $75 \%$ replacement from sand with silica fume as additive by percent 5,10 , and $15 \%$ by cement weight. Phase II, the above experiment is repeated with 
the same components but with different content of cement. This content is $450 \mathrm{~kg} / \mathrm{m}^{3}$.

The mechanical properties of green concrete were measured in term of compressive strength, indirect tensile (splitting tensile), flexural strengths, static modulus of elasticity test, and permeability test. The properties were measured at age 28 days indirect tensile (splitting tensile), flexural strengths, static modulus of elasticity test, and permeability test. For compressive strength were measured at 7,28 and 90 days.

\section{3- Materials Properties}

Test specimens were prepared from available local materials. These include natural siliceous sand, crushed stone from Suez area, ordinary Portland cement OPC Suez Cement Company, tap drinking water, silica fume, chemical admixture, limestone waste from Suez area. Testing of these materials was carried out according to Egyptian Standard Specification. The silica fume (SF) used was obtained from factories of Egyptian Ferro-alloys Company located in Aswan, Egypt. A super-plasticizer namely (ADDICRETE BVF) was used. It is supplied from chemicals for modern building company. It meets the requirements of super-plasticizer according to ASTM C494-80 type $\mathrm{A}$ and $\mathrm{F}^{6}$. The chemical properties of the LSW used are shown in tables 1. Table 2 shows the physical and mechanical properties of LSW used.

Table 1: The Chemical characteristics of the (LSW)

\begin{tabular}{|c|c|}
\hline Property \% & Results \% \\
\hline $\mathrm{SiO} 2$ & 6.49 \\
\hline $\mathrm{A} 12 \mathrm{O} 3$ & 0.78 \\
\hline $\mathrm{Fe} 2 \mathrm{O} 3$ & 0.36 \\
\hline $\mathrm{CaO}$ & 34.95 \\
\hline $\mathrm{MgO}$ & 14.44 \\
\hline $\mathrm{SO} 3$ & 0.67 \\
\hline $\mathrm{Na} 2 \mathrm{O}$ & 0.10 \\
\hline $\mathrm{K} 2 \mathrm{O}$ & 0.40 \\
\hline $\mathrm{CL}$ & 0.61 \\
\hline Loss on Ignition (L.O.I) & 41 \\
\hline
\end{tabular}

Table 2: Physical and mechanical properties of limestone waste (LSW)

\begin{tabular}{|c|c|c|}
\hline Property & Results & Limits \\
\hline Specific Weight & 2.61 & ---- \\
\hline Bulk Density (t/m3) & 1.56 & ---- \\
\hline Water Absorption \% & 20.5 & $\begin{array}{c}\text { Not more than } \\
2.5^{* *}\end{array}$ \\
\hline $\begin{array}{c}\text { Clay and Fine Dust } \\
\text { Content \% }\end{array}$ & 2.4 & $\begin{array}{c}\text { Not more than } \\
4^{*}\end{array}$ \\
\hline $\begin{array}{c}\text { Flakiness Index \% } \\
40^{*}\end{array}$ \\
\hline Abrasion Index \% & 36.8 & $\begin{array}{c}\text { Not more than } \\
30^{*}\end{array}$ \\
\hline
\end{tabular}

*Limits of ESS 1109/2002 7 ,

** Limits of ECCS203-2007 ${ }^{8}$

\section{4- Concrete Mix}

Mixing was done in a standard drum-type mixer. Course and fine aggregate were first mixed in dry state until the mixture become homogenous. All binder materials (cement, and silica fume) were added to the dry mixture, and mixing continued until the mixture become homogenous. Finally, the mixing water containing the superplasticizer admixture was added to the rotating mixer and mixing continued to assure complete homogeneity. The concrete mixes were designed at fixed water-cement ratio of 0.47 . In phase I, and II, the concrete mixes were designed to have a near constant slump in the range of $90-110 \mathrm{~mm}$.

\section{5- Details of Specimen}

Compression test at 7, 28, and 90 days was carried out on $150 \times 150 \times 150 \mathrm{~mm}$ cubes $^{9}$. Splitting test at 28 days was carried out on $150 \times 300 \mathrm{~mm}$ cylinder ${ }^{10}$. Flexural strength test at 28 days was carried out on $100 \times 100 \times$ $500 \mathrm{~mm}$ prisms ${ }^{11}$. Static modulus of elasticity at 28 days was carried out on $150 \times 300 \mathrm{~mm}^{\text {cylinder }}{ }^{12}$. Water permeability test at 28 days was carried out on $150 \times 150 \mathrm{~mm}$ cylinder ${ }^{12}$. All the test specimens were demoded after 24 hours and then stored under water in curing tanks with room temperature $\left(25 \pm 2^{\circ} \mathrm{C}\right)$. The test was carried out according to Egyptian Stander Specifications ESS 1658-1991 Part $7^{13}$.

\section{6- Test Results}

\section{6-1 Effect of Cement Content}

The compressive strength was studied at 7, 28, and 90 days. From tables 3, 4 and Fig. 1, the effect of the cement content on the compressive strength of similar mixes can be seen. According to these results, the compressive strength of mix containing cement content 
of $450 \mathrm{~kg} / \mathrm{m}^{3}$ is higher than the strength of mix prepared with $350 \mathrm{~kg} / \mathrm{m}^{3}$.

The increase in the cement content resulted in an increase in the compressive strength of the normal concrete mixes as expected. About $20 \%$ strength gain was obtained when the cement content increased from $350 \mathrm{~kg} / \mathrm{m}^{3}$ to $450 \mathrm{~kg} / \mathrm{m}^{3}$ at 28 days. And these results were obtained at all other testes.

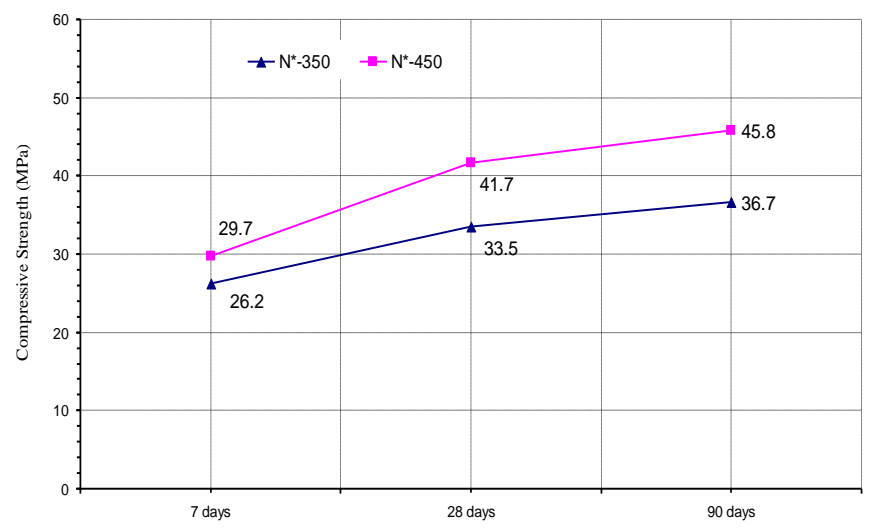

Fig.1: Effect of cement content in mix control on the compressive strength phase $\mathrm{I}\left(350 \mathrm{~kg} / \mathrm{m}^{3}\right)$

Table 3: Result of the compressive strength specimens group (A) phase I

\begin{tabular}{|c|c|c|c|c|c|}
\hline \multirow{2}{*}{$\begin{array}{c}\text { Mix } \\
\text { symbol }\end{array}$} & \multirow{2}{*}{$\begin{array}{c}\% \\
\text { LSW }\end{array}$} & \multirow{2}{*}{$\begin{array}{l}\% \\
\text { S.F }\end{array}$} & \multicolumn{3}{|c|}{$\begin{array}{l}\text { Compressive } \\
\text { strength (Mpa) }\end{array}$} \\
\hline & & & $\begin{array}{c}7 \\
\text { days }\end{array}$ & $\begin{array}{c}28 \\
\text { days }\end{array}$ & $\begin{array}{c}90 \\
\text { days }\end{array}$ \\
\hline $\mathbf{N} *_{-350}$ & 0.0 & \multirow{4}{*}{0.0} & 26.2 & 33.5 & 36.7 \\
\hline $\mathbf{N}_{25-350}$ & 25 & & 27.9 & 38.1 & 39.7 \\
\hline $\mathbf{N}_{50-350}$ & 50 & & 29.3 & 37.7 & 40.9 \\
\hline $\mathbf{N}_{75-350}$ & 75 & & 28.1 & 31.8 & 35.2 \\
\hline $\mathbf{S}_{1-350}$ & \multirow{3}{*}{0.0} & 5 & 33.1 & 41.7 & 49.7 \\
\hline $\mathbf{S}_{2-350}$ & & 10 & 39.6 & 48.6 & 52.1 \\
\hline $\mathbf{S}_{3-350}$ & & 15 & 43.1 & 51.2 & 54.4 \\
\hline $\mathbf{S}_{4-350}$ & \multirow{3}{*}{25} & 5 & 41 & 42.9 & 46.9 \\
\hline $\mathbf{S}_{5-350}$ & & 10 & 43.9 & 49.3 & 52.8 \\
\hline $\mathbf{S}_{6-350}$ & & 15 & 46.5 & 53.6 & 56.3 \\
\hline $\mathbf{S}_{7-350}$ & \multirow{3}{*}{50} & 5 & 34.6 & 43.2 & 48.4 \\
\hline $\mathbf{S}_{8-350}$ & & 10 & 40.1 & 52.1 & 53.3 \\
\hline $\mathbf{S}_{9-350}$ & & 15 & 43.6 & 55.8 & 56.7 \\
\hline $\mathbf{S}_{10-350}$ & \multirow{3}{*}{75} & 5 & 28.8 & 37.5 & 40.3 \\
\hline $\mathbf{S}_{11-350}$ & & 10 & 31.9 & 44.7 & 47.9 \\
\hline $\mathbf{S}_{12-350}$ & & 15 & 34.2 & 47.5 & 52.1 \\
\hline
\end{tabular}

Table 4: Result of the compressive strength specimens group (C) phase II

\begin{tabular}{|c|c|c|c|c|c|}
\hline \multirow{2}{*}{$\begin{array}{c}\text { Mix } \\
\text { symbol }\end{array}$} & \multirow{2}{*}{$\underbrace{0}_{0}$} & \multirow{2}{*}{$\begin{array}{l}\text { 盾 } \\
\text { so }\end{array}$} & \multicolumn{3}{|c|}{$\begin{array}{c}\text { Compressive strength } \\
\text { (Mpa) }\end{array}$} \\
\hline & & & 7 days & $\begin{array}{c}28 \\
\text { days }\end{array}$ & $\begin{array}{c}90 \\
\text { days }\end{array}$ \\
\hline $\mathrm{N}^{*}-450$ & 0.0 & \multirow{4}{*}{0.0} & 29.7 & 41.7 & 45.8 \\
\hline $\mathrm{N}_{25-450}$ & 25 & & 31.5 & 41.9 & 48.4 \\
\hline $\mathrm{N}_{50-450}$ & 50 & & 28.9 & 40.3 & 45.2 \\
\hline $\mathrm{N}_{75-450}$ & 75 & & 27.1 & 38.2 & 44.3 \\
\hline $\mathbf{S}_{1-450}$ & \multirow{3}{*}{0.0} & \multirow{3}{*}{$\begin{array}{c}5 \\
10 \\
15\end{array}$} & 40.1 & 48.4 & 51.2 \\
\hline $\mathbf{S}_{2-450}$ & & & 46.7 & 57.4 & 58.8 \\
\hline $\mathbf{S}_{3-450}$ & & & 49.4 & 61.1 & 62.2 \\
\hline $\mathbf{S}_{4-450}$ & \multirow{3}{*}{25} & \multirow{3}{*}{$\begin{array}{c}5 \\
10 \\
15\end{array}$} & \multirow{3}{*}{$\begin{array}{l}42.7 \\
48.5 \\
50.9\end{array}$} & \multirow{3}{*}{$\begin{array}{c}50.8 \\
58 \\
62\end{array}$} & \multirow{3}{*}{$\begin{array}{l}52.3 \\
59.6 \\
62.8\end{array}$} \\
\hline $\mathbf{S}_{5-450}$ & & & & & \\
\hline $\mathbf{S}_{6-450}$ & & & & & \\
\hline $\mathbf{S}_{7-450}$ & \multirow{3}{*}{50} & \multirow{3}{*}{$\begin{array}{c}5 \\
10 \\
15\end{array}$} & \multirow{3}{*}{$\begin{array}{l}34.9 \\
36.8 \\
39.8\end{array}$} & \multirow{3}{*}{$\begin{array}{l}46.5 \\
48.7 \\
52.1\end{array}$} & \multirow{3}{*}{$\begin{array}{l}48.6 \\
52.2 \\
54.4\end{array}$} \\
\hline $\mathbf{S}_{8-450}$ & & & & & \\
\hline $\mathbf{S}_{9-450}$ & & & & & \\
\hline $\mathbf{S}_{10-450}$ & \multirow{3}{*}{75} & \multirow{3}{*}{$\begin{array}{c}5 \\
10 \\
15\end{array}$} & \multirow{3}{*}{$\begin{array}{c}31.1 \\
35 \\
37.7\end{array}$} & \multirow{3}{*}{$\begin{array}{l}45.2 \\
48.6 \\
53.3\end{array}$} & \multirow{3}{*}{$\begin{array}{l}49.6 \\
52.3 \\
57.3\end{array}$} \\
\hline $\mathbf{S}_{11-450}$ & & & & & \\
\hline $\mathbf{S}_{12-450}$ & & & & & \\
\hline
\end{tabular}

\section{6-2 Normal Concrete phase I}

\section{6-2-1 Effect of Limestone Waste (LSW)}

Compressive strength test results of normal concrete with LSW with different replacement percentages are presented in table 3 and Fig. 2 for 0.0, 25, 50, and 75\% respectively. Using LSW with levels $25 \%$ and $50 \%$ increased compressive strength of normal concrete about $(6 \%, 12 \%, 8 \%)_{25},(10 \%, 11 \%, 10 \%)_{50}$ at 7,28 and 90 days respectively, as compared with the normal concrete $\mathrm{N}^{*}{ }_{-350}$. Using LSW with level $75 \%$ increased compressive strength of normal concrete about $6 \%$ at 7 days as compared with the normal concrete $\mathrm{N}_{-350}$. On the other hand, there is reduction about $5 \%$ and $4 \%$ at 28 and 90 days respectively, when replacement level of $75 \%$, as compared with the normal concrete $\mathrm{N}^{*}{ }_{-350}$. The loss of the compressive strength at a replacement level $75 \%$ can be related to its physical and chemical effects for limestone powder. Moreover, the percentage of free calcium hydroxide during the reaction of cement is increase, when powder content in LSW increases ${ }^{5}$. 


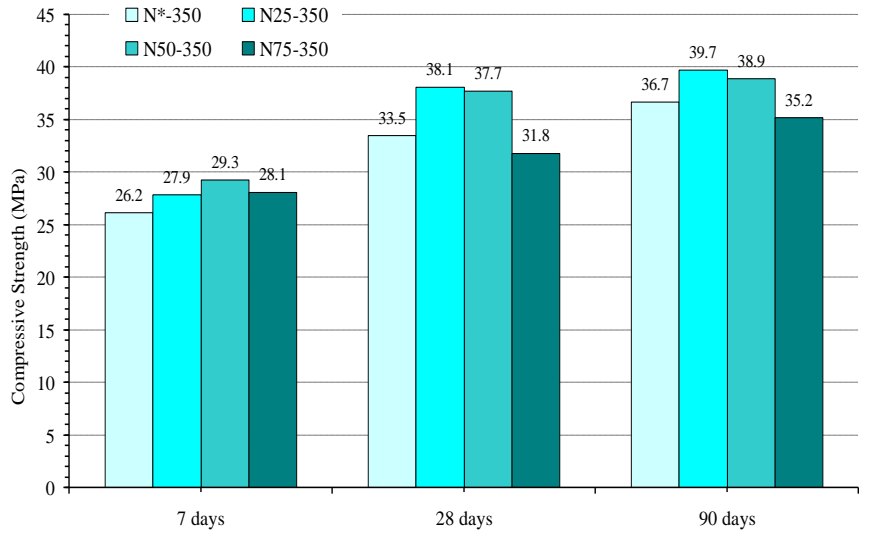

Fig. 2: Effect of $25 \%, 50 \%$ and $75 \% \mathrm{LSW}$ as a replacement from sand, on the compressive strength concrete, phase I $\left(350 \mathrm{~kg} / \mathrm{m}^{3}\right)$

\section{6-2-2 Effect of Silica Fume (S.F)}

Compressive strength test results of normal concrete with S.F with different addition percentages 5, 10 and $15 \%$ respectively are presented in Fig. 3. The appropriate use of S.F improves both the mechanical characteristics and the durability of concrete ${ }^{14}$. Using S.F as an additive in the concrete mixes show that the compressive strength increased about $20 \%, 31 \%$ and $34 \%$ for $5 \%, 10 \%$ and $15 \%$ S.F as an addition from the cement weight, at 28 days respectively. Also, it can be observed that the increased in compressive strength for higher ages it was not with the same range. The limited gain of strength as the percentage of S.F increased from 10 and $15 \%$ may be explained that S.F content become in excess of the amount required to react with the available $\mathrm{Ca}(\mathrm{OH})_{2}$ which was formed due to the cement hydration process.

The increase of strength due to the presence of S.F can be related to its physical and chemical effects ${ }^{15}$, ${ }^{16}$. The used of S.F can be enhancement the transition zone between aggregate and cement baste in concrete. This enhanced bonding is associated with the formation of a dense microstructure in the transition zone of the concrete containing S.F ${ }^{17}$. The used of S.F can be enhancement the compressive strength between 1 to 90 days. However, the compressive strength of concrete mixtures containing silica fume did not increase after the age of 90 days ${ }^{18}$.

\section{6-3 Green Concrete}

\section{6-3-1 Effect of LSW Content, with S.F}

Compressive strength of green concrete with $25 \%$, $50 \%$, and $75 \%$ LSW replacement at different percentages 5, 10, and 15\% S.F respectively, are presented in Figs. $(4,5,6)$ and table 3 . It can be observed that, the compressive strength markedly increased at different ages. The highest increase at $15 \%$ S.F. Using $(25 \%, 50 \%$, and $75 \%) \mathrm{LSW}$ with $15 \%$ S.F increased the compressive strength about $(28 \%$, $32 \%$, and $33 \%$ ) as compared with normal mix $\mathrm{N}_{25-350}$, $\mathrm{N}_{50-350}, \mathrm{~N}_{75-350}$ at 28 days, respectively. But using LSW with S.F increased the compressive strength about $(3 \%, 1 \% \text { and } 5 \%)_{25},(3 \%, 6 \% \text { and } 8 \%)_{50}$ and $(10 \%$, $8 \%$ and $7 \%)_{75}$, respectively as compared with concrete containing S.F only as an additive materials, at 28 days. The results derived from compressive strength tests showed that LSW was more effective than S.F in terms of early strength gain, this results in agreement with S. turkel et. al., ${ }^{19}$

The combined use of LSW and S.F exhibited excellent performance due to efficient micro filling ability and pozzolanic activity of S.F ${ }^{20}$.

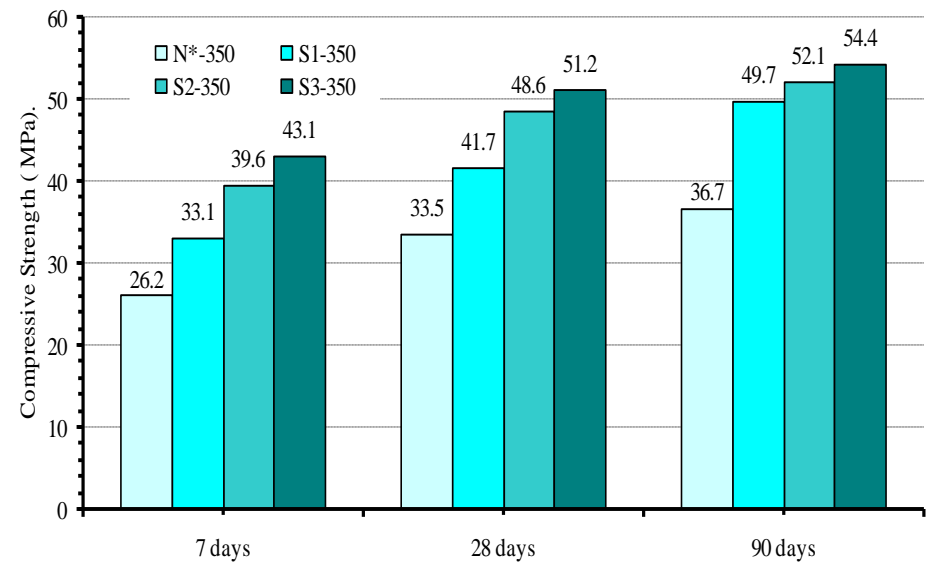

Fig 3: Effect of S.F contents as an addition material from cement weight, on compressive strength,

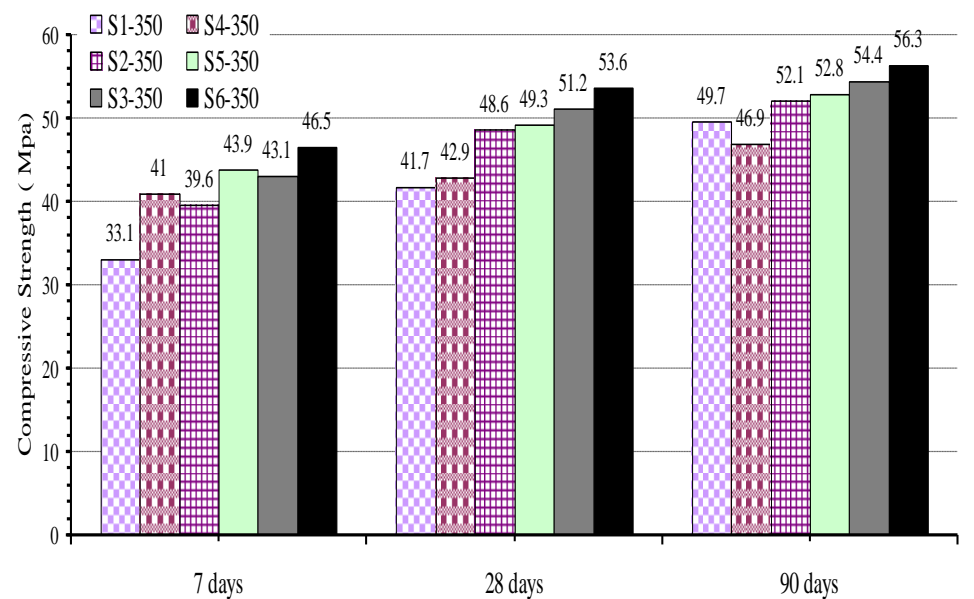

Fig4: Effect of $25 \%$ LSW, with 5, 10 and $15 \%$ S.F, as addition by weight from cement, phase I $\left(350 \mathrm{~kg} / \mathrm{m}^{3}\right)$ 


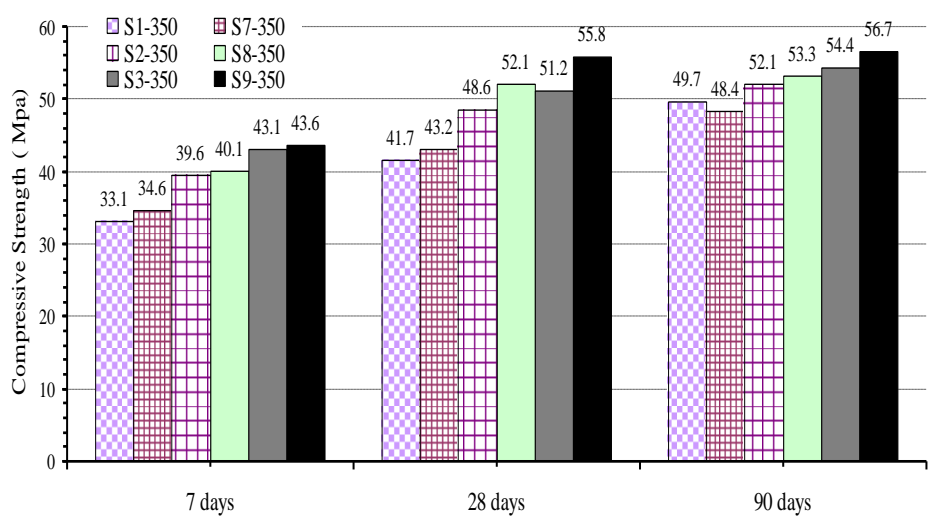

Fig5: Effect of $50 \%$ LSW, with 5, 10 and $15 \%$ S.F, as addition by weight from cement, phase I $\left(350 \mathrm{~kg} / \mathrm{m}^{3}\right)$

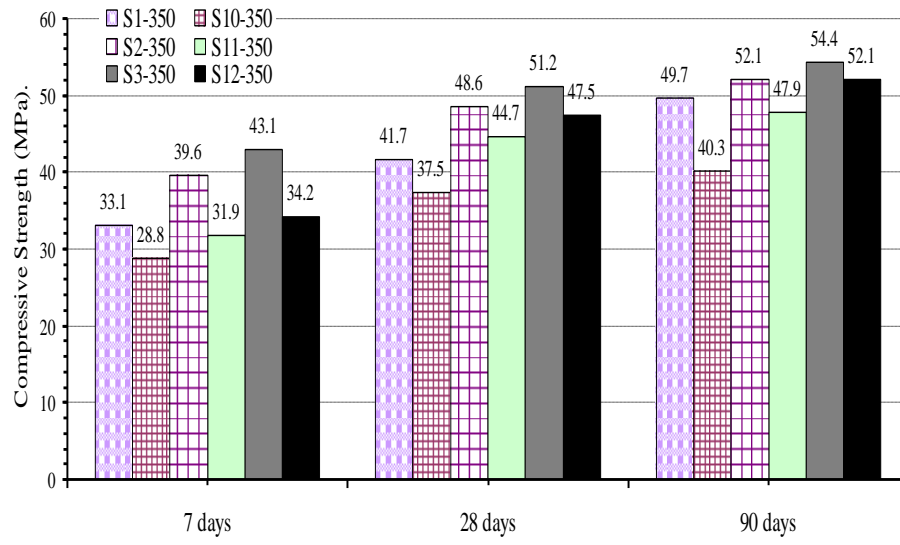

Fig6: Effect of $75 \%$ LSW, with 5, 10 and $15 \%$ S.F, as addition by weight from cement, phase $\mathrm{I}\left(350 \mathrm{~kg} / \mathrm{m}^{3}\right)$

It can be observed that the negative effects of reduced compressive strength in the green concrete was compensated by the inclusion of S.F into the concrete. Concrete containing S.F has recorded reduction in compressive strength than the green concrete containing $25 \%$ and $50 \%$ LSW with 5,10 , and $15 \%$ S.F. On the other hand, concrete containing S.F has recorded higher compressive strength than the green concrete containing $75 \% \mathrm{LSW}$ with 5,10 , and $15 \%$ S.F. The beneficial effects of S.F in the strength development and durability properties of concrete are widely accepted. The contribution of S.F to the positive effects in the strength in concrete has been attributed to direct water reduction, the increase in the effective volume of paste in the mix and its pozzolanic reaction. Besides the effect of chemical reaction, S.F has a physical effect of improving the microstructure of the hydrated cement paste. Therefore, it can be mentioned that LSW can be utilized as partial replacement material from sand, in the presence of S.F, to produce concretes with accepted range of compressive $\operatorname{strength}^{3,} 5$, and 15 . Incorporation of S.F in concrete significantly increased the compressive strength compared to control $^{21}$.

\section{6-4 Normal Concrete Phase II}

\section{6-4-1 Effect of Limestone Waste (LSW)}

Compressive strength test results of normal concrete with LSW with different replacement percentages are presented in table 4, and Fig. 7 for 0.0, 25, 50, and $75 \%$, respectively. Using LSW with level $25 \%$ increased compressive strength of normal concrete about $5 \%, 0.5 \%, 5 \%$ at 7,28 and 90 days respectively, as compared with the normal concrete $\mathrm{N}^{*}-450$. On the other hand using LSW with levels 50\% and75\% decreased compressive strength of normal concrete about $(2 \%, 3 \%, 1 \%)_{50},(8 \%, 8 \%, 3 \%)_{75}$ at 7,28 and 90 days respectively, as compared with the normal concrete $\mathrm{N}^{*}{ }_{-450}$. The reduction in the compressive strength of concrete is probably due to the large amount of calcium hydroxide resulting from the hydration process of the cement and LSW. Moreover, the loss of the compressive strength at a replacement level $50 \%$ and $75 \%$ can be related to its physical and chemical effects for limestone powder. Moreover, the percentage of free calcium hydroxide during the reaction of cement is increase, when powder content in LSW increases 5 .

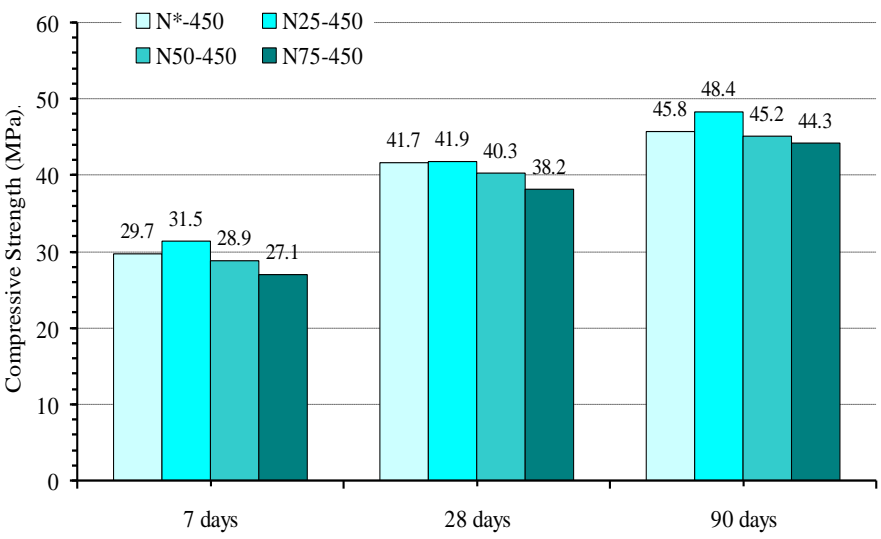

Fig 7: Effect of $25 \% \mathrm{LSW}$ as a replacement from sand, on the compressive strength concrete, phase II $\left(450 \mathrm{~kg} / \mathrm{m}^{3}\right)$

\section{6-4-2 Effect of Silica Fume (S.F)}

Compressive strength test results of normal concrete with S.F with different addition percentages 5, 10, and $15 \%$ respectively, are presented in table 4 , Fig. 8 . The appropriate use of S.F improves both the mechanical characteristics and the durability of concrete ${ }^{70}$. Using S.F as an additive in the concrete mixes show that the compressive strength increased about 13\%, 27\% and $31 \%$ for $5 \%, 10 \%$ and $15 \%$ S.F as an addition from the cement weight, at 28 days respectively. Also, it can be observed that the increased in compressive strength for higher ages it was not with the same range. The limited gain of strength as the percentage of S.F increased 
from 10 and $15 \%$ may be explained that S.F content become in excess of the amount required to react with the available $\mathrm{Ca}(\mathrm{OH})_{2}$ which was formed due to the cement hydration process.

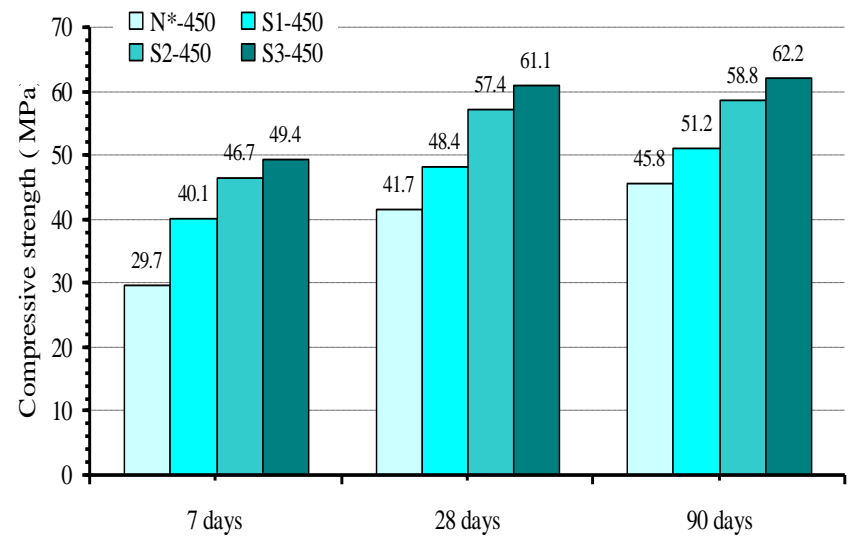

Fig 8: Effect of S.F contents as an addition materials from cement weight, phase II $\left(450 \mathrm{~kg} / \mathrm{m}^{3}\right)$

\section{6-5 Green Concrete}

\section{6-5-1 Effect of (LSW) Content, With (S.F)}

Compressive strength of green concrete with $25 \%$, $50 \%$, and $75 \%$ LSW replacement at different percentages 5, 10, and $15 \%$ S.F respectively, are presented in Figs. $(9,10,11)$ and table 4 . It can be observed that, the compressive strength markedly increased at different ages. The highest increase at $15 \%$ S.F. Using $(25 \%, 50 \%$, and $75 \%) \mathrm{LSW}$ with $15 \%$ S.F increased the compressive strength about $32 \%, 22 \%$, and $28 \%$ as compared with normal mix $\mathrm{N}_{25-450}, \mathrm{~N}_{50-540}$, and $\mathrm{N}_{75-450}$ at 28 days, respectively. Moreover, using LSW with S.F increased the compressive strength about $(4 \%, 1 \% \text { and } 1 \%)_{25},(3 \%$, $15 \%$ and $14 \%$ ) 50 , and $(6 \%, 15 \%$ and $12 \%) 75$ as compared with concrete containing S.F only as additive materials, at 28 days, respectively. It can be observed that the negative effects of reduced compressive strength in the green concrete were compensated by the inclusion of S.F into the concrete. Concrete containing S.F has recorded reduction in compressive strength than the green concrete containing $25 \% \mathrm{LSW}$ with 5,10 , and $15 \%$ S.F. On the other hand, concrete containing S.F has recorded higher compressive strength than the green concrete containing $50 \%$ and $75 \%$ LSW with 5,10 , and $15 \%$ S.F. The beneficial effects of S.F in the strength development and durability properties of concrete are widely accepted. The contribution of S.F to the positive effects in the strength in concrete has been attributed to direct water reduction, the increase in the effective volume of paste in the mix and its pozzolanic reaction. Besides the effect of chemical reaction, S.F has a physical effect of improving the microstructure of the hydrated cement paste. Therefore, it can be mentioned that LSW can be utilized as partial replacement material from sand, in the presence of S.F, to produce concretes with accepted range of compressive strength $\mathrm{h}^{3,5}$, and 15 .

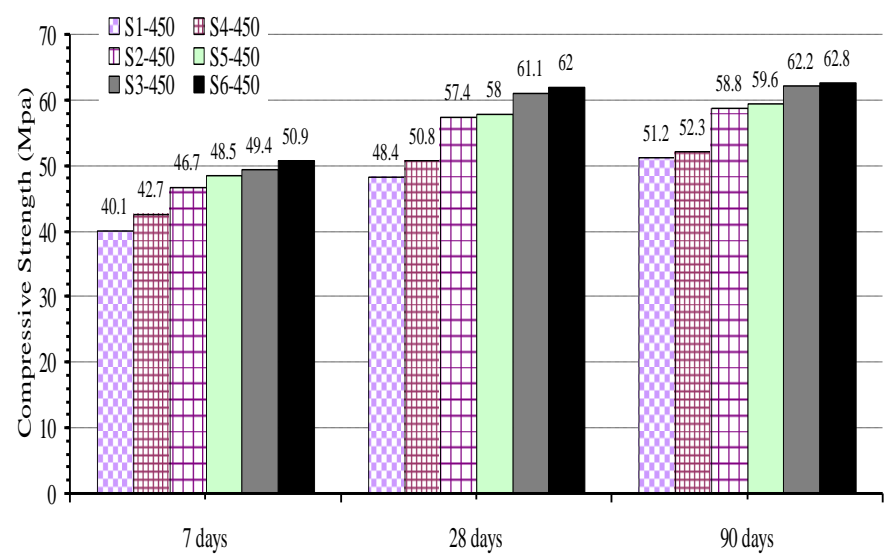

Fig 9: Effect of $25 \%$ LSW, with 5, 10 and $15 \%$ S.F, as an addition by weight from cement phase II $\left(450 \mathrm{~kg} / \mathrm{m}^{3}\right)$

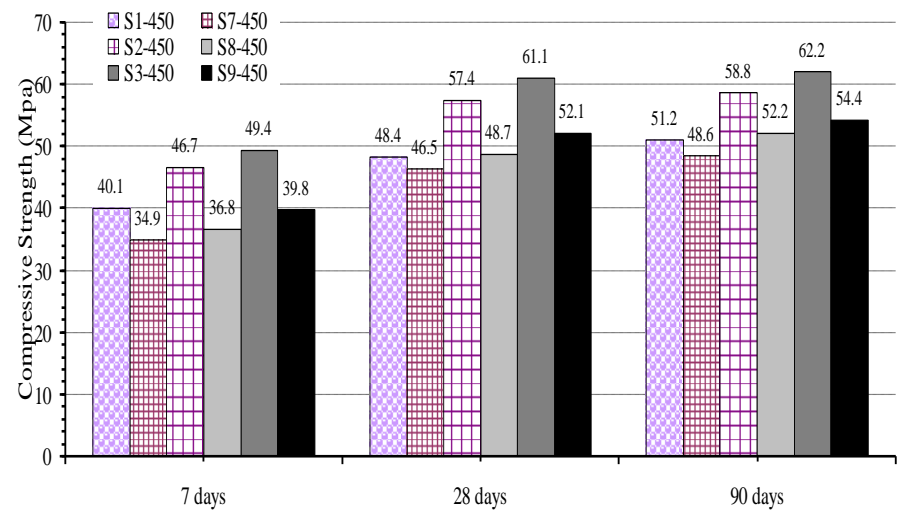

Fig 10: Effect of 50\% LSW, with 5, 10 and $15 \%$ S.F, as an addition by weight from cement phase II $\left(450 \mathrm{~kg} / \mathrm{m}^{3}\right)$

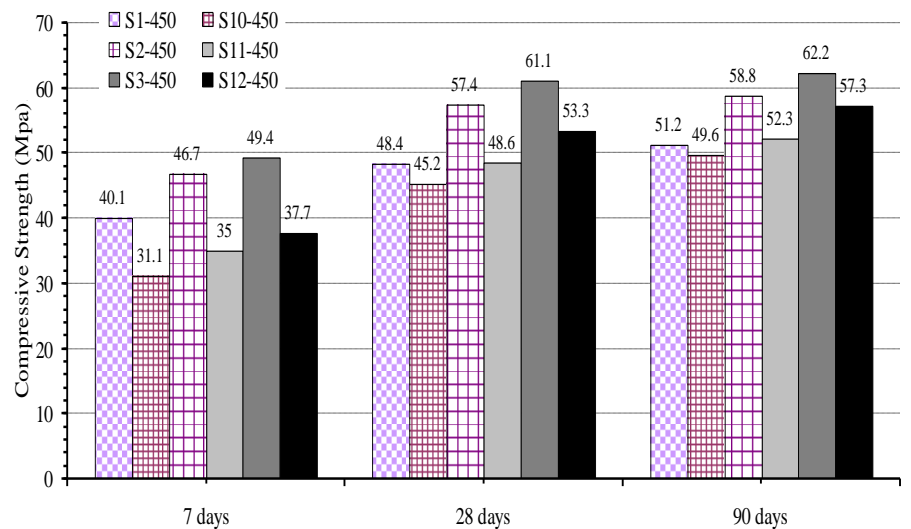

Fig 11: Effect of $75 \%$ LSW, with 5, 10 and $15 \%$ S.F, as addition by weight from cement phase II $\left(450 \mathrm{~kg} / \mathrm{m}^{3}\right)$ 


\section{6-6 Tensile Strength}

Tables 5, 6 and Figs $(12,13)$ show the results of the splitting tensile strength for normal concrete specimens and specimens having 50\% LSW as a replacement from sand by weight with S.F with $15 \%$ as addition by weight from cement. The above experiment is being done on the phases I and II.

Table 5: The tensile strength of concrete specimens, for selected mixes group (A), phase I

\begin{tabular}{|c|c|c|c|c|}
\hline \multirow{3}{*}{$\begin{array}{c}\text { Mix } \\
\text { symbol }\end{array}$} & \multirow{3}{*}{$\begin{array}{c}\% \\
(\mathrm{LSW})\end{array}$} & \multirow{3}{*}{$\begin{array}{c}\% \\
\text { (S.F) }\end{array}$} & \multicolumn{2}{|c|}{$350 \mathrm{Kg} / \mathrm{m}^{3}$} \\
\hline & & & $\begin{array}{c}f_{s p, 28} \\
d a y\end{array}$ & $f_{s p} / f_{c u}$ \\
\hline & & & $M p a$ & \\
\hline $\mathbf{N}^{*}-350$ & 0 & 0 & 3.7 & 11 \\
\hline $\mathbf{S}_{3-350}$ & 0 & 15 & 6.1 & 11.9 \\
\hline $\mathbf{S}_{9-350}$ & 50 & 15 & 6.5 & 11.6 \\
\hline
\end{tabular}

Table 6: The tensile strength of concrete specimens, for selected mixes group (C), phase II

\begin{tabular}{|c|c|c|c|c|}
\hline \multirow{2}{*}{$\begin{array}{c}\text { Mix } \\
\text { symbol }\end{array}$} & \multirow{2}{*}{$\begin{array}{c}\% \\
(\mathrm{LSW})\end{array}$} & \multirow{2}{*}{$\begin{array}{c}\% \\
\text { (S.F) }\end{array}$} & $\begin{array}{c}|c| \\
f_{s p}, 28 \\
\text { day }\end{array}$ & \multirow{2}{*}{$f_{s p} / f_{c u}$} \\
\cline { 4 - 5 } & & & $M p a$ & \\
\hline $\mathbf{N}^{*}-450$ & 0 & 0 & 4.7 & 11.3 \\
\hline $\mathbf{S}_{3-450}$ & 0 & 15 & 7.4 & 12.1 \\
\hline $\mathbf{S}_{9-450}$ & 50 & 15 & 7.1 & 13.6 \\
\hline
\end{tabular}

\section{6-6-1 Effect of LSW Content, With S.F}

Splitting tensile strength of green concrete with $50 \%$ LSW replacement at different $15 \%$ S.F is presented in Figs. $(12,13)$ and tables $(5,6)$ respectively, It can be observed that, the splitting tensile strength markedly increased at 28 days. Using 50\% LSW with $15 \%$ S.F increased the splitting tensile strength about $43 \%$ as compared with normal concrete mix $\mathrm{N}^{*}{ }_{-350}$. On the other hand, using 50\% LSW with $15 \%$ S.F increased the splitting tensile strength about $33 \%$ as compared with normal concrete mix $\mathrm{N}^{*}-450$. As shown from tables $(5,6)$, the ratio of the indirect tensile strength to the compressive strength $\left(\mathbf{f}_{\mathrm{sp}} / \mathbf{f}_{\mathrm{cu}}\right)$ of the mix containing $50 \%$ from LSW as replacement from sand weight, and $15 \%$ S.F as an addition by weight from cement, was generally similar to that of the corresponding normal concrete mix at the same cement content. This result agree with ${ }^{67}$ who concluded that a very small growing in this noticed for the concrete containing, 50\% LSW and 15\% S.F as well as the normal concrete mix with the increase of the cement content.

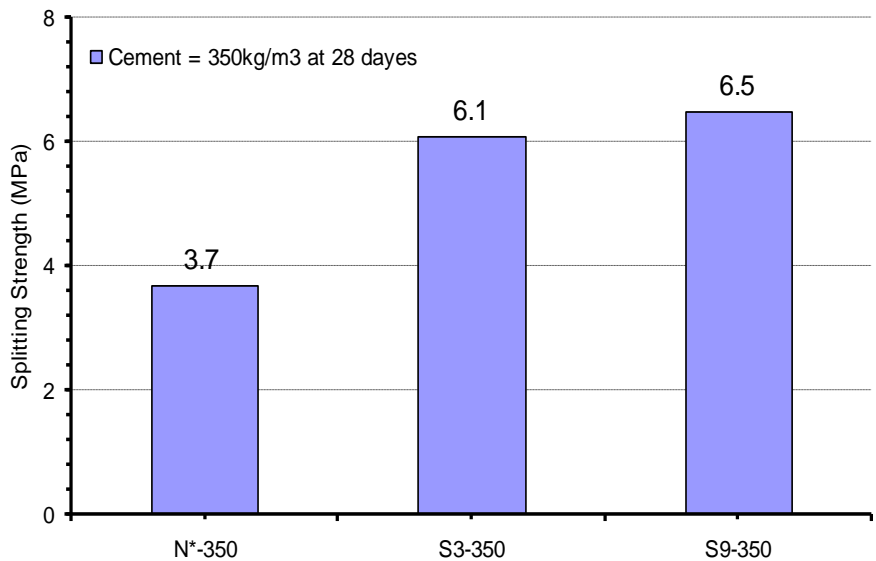

Fig 12: Effect of S.F and LSW with S.F on the tensile strength, phase $\mathrm{I}\left(350 \mathrm{~kg} / \mathrm{m}^{3}\right)$

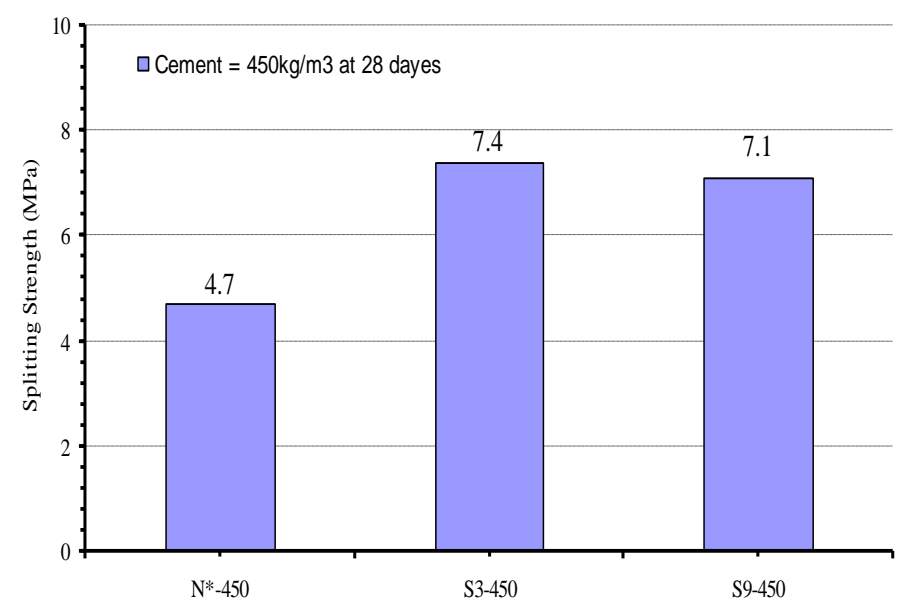

Fig13: Effect of S.F and LSW with S.F on the tensile strength, phase II $\left(450 \mathrm{~kg} / \mathrm{m}^{3}\right)$

\section{6-7 Flexural Strength}

Tables $(7,8)$ and Figs $(14,15)$ show the results of the Flexural strength for normal concrete specimens and specimens having $50 \% \mathrm{LSW}$ as a replacement from sand by weight, with S.F by $15 \%$ as addition by weight from cement. The above experiment is being done on the phases I and II. 
Table 7: Flexural strength of concrete specimens, for selected mixes group (A) phase I

\begin{tabular}{|c|c|c|c|c|}
\hline \multirow{2}{*}{$\begin{array}{c}\text { Mix } \\
\text { symbol }\end{array}$} & \multirow{2}{*}{$\begin{array}{c}\% \\
(\mathrm{LSW})\end{array}$} & \multirow{2}{*}{$\begin{array}{c}\% \\
\text { (S.F) }\end{array}$} & \multicolumn{2}{|c|}{$350 \mathrm{Kg} / \mathrm{m}^{3}$} \\
\cline { 4 - 5 } & & & $M p a$ & \\
\hline $\mathbf{N}^{*}$-350 & 0 & 0 & 5.69 & 18.2 \\
\hline $\mathbf{S}_{3-350}$ & 0 & 15 & 7.16 & 19.1 \\
\hline $\mathbf{S}_{9-350}$ & 50 & 15 & 7.3 & 19.8 \\
\hline
\end{tabular}

Table 8: Flexural strength of concrete specimens, for selected mixes group (C) phase II

\begin{tabular}{|c|c|c|c|c|}
\hline \multirow{2}{*}{$\begin{array}{c}\text { Mix } \\
\text { symbol }\end{array}$} & \multirow{2}{*}{$\begin{array}{c}\% \\
(\mathrm{LSW})\end{array}$} & \multirow{2}{*}{$\begin{array}{c}\% \\
(\mathrm{~S} . \mathrm{F})\end{array}$} & \multicolumn{2}{|c|}{$450 \mathrm{Kg} / \mathrm{m}^{3}$} \\
\cline { 4 - 5 } & & & $M p a$ & \\
\hline $\mathbf{N}^{*}$-45 $28 \mathrm{day}$ & $f_{\mathrm{fl}} / f_{\mathrm{cu}}$ \\
\hline $\mathbf{S}_{3-450}$ & 0 & 0 & 7.6 & 17.7 \\
\hline $\mathbf{S}_{9-450}$ & 50 & 15 & 10.7 & 17.5 \\
\hline
\end{tabular}

\section{6-7-1 Effect of LSW Content, With S.F}

Flexural strength of green concrete with $50 \%$ LSW replacement with $15 \%$ S.F is presented in Figs (14, $15)$, and tables $(7,8)$. It can be observed that, the flexural strength markedly increased at 28 days. Using 50\% LSW with 15\% S.F increased the flexural strength about $21 \%$ as compared with normal concrete mix $\mathrm{N}_{-350}$.

On the other hand, using 50\% LSW with $15 \%$ S.F increased the flexural strength about $25 \%$ as compared with normal concrete mix $\mathrm{N}^{*}-450$.

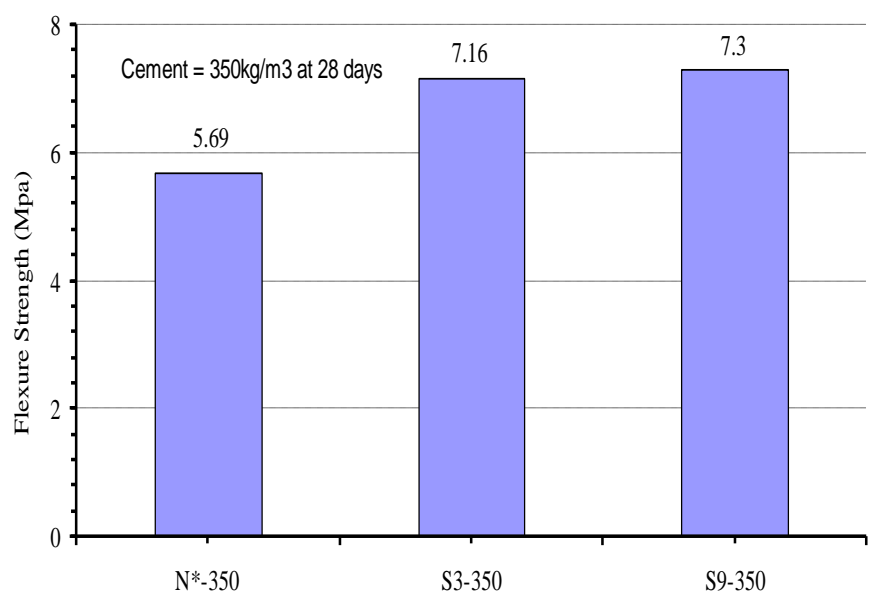

Fig. 14: Effect of S.F and LSW with S.F on the flexural strength, phase I $\left(350 \mathrm{~kg} / \mathrm{m}^{3}\right)$

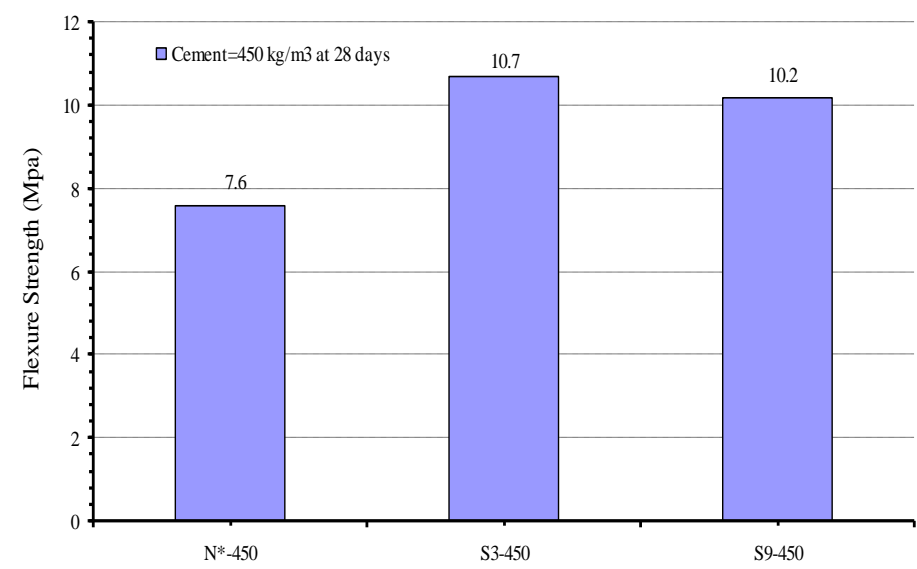

Fig.15: Effect of S.F and LSW with S.F on the flexural strength, phase II $\left(450 \mathrm{~kg} / \mathrm{m}^{3}\right)$

\section{6-8 Modulus of Elasticity}

\section{6-8-1Effect of (LSW) Content, With (S.F)}

It is obvious from the results of modulus of elasticity of green concrete increased with increasing the LSW with S.F. The limited gain of the modulus of elasticity was up to $9.2 \%$ and $26.7 \%$ as compared with normal concrete mix $\mathrm{N}_{-350}$. On the other hand, the limited gain of the modulus of elasticity was up to $1.8 \%$ and $6.5 \%$ as compared with normal concrete mix $\mathrm{N}^{*}-450$.

\section{6-9 Water Permeability}

The water permeability of concrete are presents by the average coefficient of permeability, $\mathrm{K}$, for the three concrete test cylinders. It can be observed that the coefficient of permeability, $\mathrm{K}$, decreases as the dust content increases. The highest coefficient of permeability was $6.8 \times 10^{-10} \mathrm{~cm} / \mathrm{sec}$ for normal concrete mix $\mathrm{N}_{-350}$, and the lowest was $4.49 \times 10^{-10} \mathrm{~cm} / \mathrm{sec}$ for mix content $15 \%$ S.F. As the same time the coefficient of permeability was $4.23 \times 10^{-10} \mathrm{~cm} / \mathrm{sec}$ for mix content $50 \%$ LSW, with $15 \%$ S.F.

As the same time is happen in concrete containing cement $450 \mathrm{~kg} / \mathrm{m}^{3}$, it can be observed that the coefficient of permeability, $\mathrm{K}$, decreases as the dust content increases. The highest coefficient of permeability was $6.03 \times 10^{-10} \mathrm{~cm} / \mathrm{sec}$ for normal concrete mix $\mathrm{N}^{*}-450$, and the lowest was $3.98 \times 10^{-}$ ${ }^{10} \mathrm{~cm} / \mathrm{sec}$ for mix content $15 \%$ S.F. As the same time the coefficient of permeability was $4.1 \times 10^{-10} \mathrm{~cm} / \mathrm{sec}$ for mix content $50 \%$ LSW, with $15 \%$ S.F, and mix content $50 \%$ LSW. The addition of LSW to the concrete improves the impermeability of concrete because it blocks the passages connecting capillary pores and the 
water channels. This blockage is affected by the amount of dust content in the LSW, and the more water passages were blocked, the more reduction in the permeability of concrete specimens is observed. The permeability is decease at LSW is increased, similar findings have been reported is earlier studies ${ }^{3}$.

\section{7- Conclusions}

From the analysis and discussion of test results obtained from this research, the following conclusions can be drawn

1- The workability of green concrete did not affected by the LWS percentage.

2- Using LSW up to $50 \%$ replacement increase the compressive strength.

3- When increasing cement content from $350 \mathrm{~kg} / \mathrm{cm}^{3}$ to $450 \mathrm{~kg} / \mathrm{cm}^{3}$ in presents of the $\mathrm{LSW}$ with different percentage decrease the compressive strength.

4- Presences of silica fume with LSW (up to 50\%) increase the compressive strength in mixes with low cement content $\left(350 \mathrm{~kg} / \mathrm{cm}^{3}\right)$.

5- The same trend of results of compressive strength for other tests (indirect tensile, flexural test, modules of elasticity, and permeability)

\section{References}

1- M. S. Hameed and A. S. S. Sekar, (2009) "Properties of green concrete containing quarry rock dust and marble sludge powder as fine aggregate" India, ARPN Journal of Engineering and Applied Sciences, Vol. 4, NO. 4, pp. 83-89.

2- Md. Safiuddin, M. Z. Jumaat, M. A. Salam, M. S. Islam and R. Hashim, (2010) "Utilization of solid wastes in construction materials" Canada, International Journal of the Physical Sciences, Vol. 5 (13), pp. 1952-1963.

3- T. Celik and K. Marar, (1996) "Effects of crushed stone dust on some properties of concrete" Turkey, Cement and Concrete Research, Vol. 26, No. 7, pp. 1121-1130.

4- L. Beixing, W. Jiliang and Z. Mingkai, (2009) "Effect of limestone fines content in manufactured sand on durability of low- and highstrength concretes" China, Construction and Building Materials, Vol. 23 (2009), pp. 28462850.

5- R. Ilangovana, N. Mahendrana and K. Nagamanib, (2008) "Strength and durability properties of concrete containing quarry rock dust as fine aggregate" India, ARPN Journal of
Engineering and Applied Sciences, Vol. 3, NO. 5, pp. 20-26.

6- ASTM C494-80 type A and F "standard specification for chemical admixtures for concrete"

7- ESS 1109/2002 Egyptian Standard Specifications "concrete aggregates from natural sources"

8- ECCS Egyptian Code ECCS 203-2007

9- ESS 1658-1991 Part 5 "Egyptian Standard Specifications "method for making test cubes from fresh concrete"

10-ESS 1658-1991 Part 4 "Egyptian Standard Specifications "method for making test cylinders from fresh concrete"

11-ASTM C 293-02 "stander test method for flexural strength of concrete"

12-ASTM C 296-96 "stander test method for splitting tensile strength of cylindrical concrete specimens"

13- ESS 1658-1991 Part 7 "method of normal curing of test specimens"

14- R. J. Detwiler and P. K. Mehta (1989) "Chemical and Physical Effects of Silica Fume on the Mechanical Behavior of Concrete" ACI Materials Journal. Vol. 86, pp.609-614.

15- S. E. Z. Falaha (2009) "short and long-term properties of silica fume height strength mortar" M. Sc faculty of engineering, materials engineering dept. zagazig university.

16- B. Persson (1998) "Seven-Year Study on the Effect of Silica Fume in Concrete" Sweden, 1998 by Elsevier Science Ltd., Vol 7, pp.139-155.

17- Godman, A. Bentur (1989) "Bond Effects in High-Strength Silica Fume Concretes" Materials Journal, Vol. 86, pp. 440-449.

18- M. Mazloom, A.A. Ramezanianpour, J.J. Brooks (2004) "Effect of silica fume on mechanical properties of high-strength concrete" Iran, Cement \& Concrete Composites, Vol. 26 (2004), pp. 347-357.

19- S. Tu Rkel, Y. Altuntas (2009) " The effect of limestone powder, fly ash and silica fume on the properties of self-compacting repair mortars" Turkey, Sadhana, Vol. 34, Part 2, pp. 331-343.

20- M. Safiuddin, S.N. Raman and M.F.M. Zain (2007) "Utilization of Quarry Waste Fine Aggregate in Concrete Mixtures" Canada, Journal of Applied Sciences Research, Vol. 3(3), pp. 202-208.

21 - M.F.M. Zain, Md. Safiuddin, H. Mahmud (2000) "Development of high performance concrete using silica fume at relatively high water \pm binder ratios" Malaysia, Cement and Concrete Research Vol.30 (2000), pp. 1501-1505. 